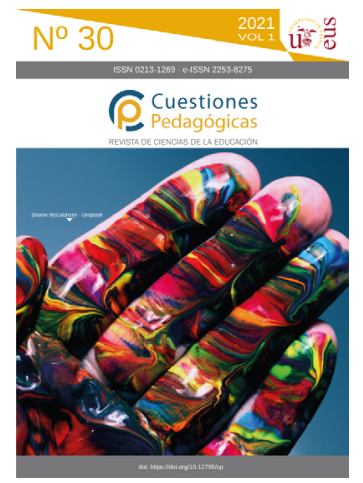

\title{
Halloween y la diversidad cultural en la Formación Inicial Docente
}

\author{
Halloween and cultural diversity in \\ pre-Service Teachers Training
}

Recibido: 25/02/2021 | Revisado: 11/06/2021 | Aceptado: 21/06/2021 | Online first: 21/06/2021 | Publicado: 01/07/2021

D Carmen García Navarro

University of Almería (Spain)

mgn024@ual.es

https://orcid.org/0000-0003-2108-6766

\author{
Manuel José López Martínez \\ University of Almería (Spain) \\ mlm138@ual.es \\ https://orcid.org/0000-0001-6653-1398
}

\begin{abstract}
Resumen: Vivimos en una sociedad en la que se corre el riesgo de familiarizarnos con una representación uniforme de la realidad socio-cultural a pesar de la diversidad en nuestro mundo globalizado. En este artículo se presenta una experiencia diseñada para promover la reflexión en el alumnado universitario sobre sus saberes para ser aplicados en el aula de Educación Infantil. Siguiendo la metodología de la investigación-acción, la finalidad es la de contribuir a la discusión y a la movilización de cambios epistemológicos y competenciales sobre la práctica docente a partir del análisis de la celebración de Halloween. El objeto de estudio se centra en el tratamiento de dicha celebración en un escenario educativo formal donde convergen diferentes universos simbólicos. Se muestran oportunidades de aprendizaje para que el futuro docente valore las potencialidades educativas interculturales de esta celebración, desde la perspectiva del cosmopolitismo y del pensamiento crítico. En esta experiencia se ha comprobado que la indagación y la reflexión crítica contribuyen a la mejora de la formación inicial del profesorado en un contexto multicultural.
\end{abstract}

Palabras clave: investigación-acción; educación de la primera infancia; formación de formadores; educación intercultural; enseñanza de lenguas; interdisciplinariedad.

\begin{abstract}
We live in a society in which we run the risk of becoming familiar with a type of uniform representation of socio-cultural reality despite the existing diversity of our globalised world. In this article an experience was designed to encourage pre-service students to think about the knowledge they could apply to early childhood education. More specifically, an action research-based methodology was used to analyze the celebration of Halloween, the purpose being to contribute to the discussion of epistemological and competence changes in teaching practice as well as to encourage efforts towards these changes. The study focused on the treatment of Halloween in a formal educational setting where different symbolic universes converge. Using an interdisciplinary and intercultural approach and favoring an active teaching and learning methodology, the foundations were laid to build a school knowledge base of English, English-speaking culture and social sciences. Learning opportunities were analyzed so that future teachers could value the intercultural and educational potential of this celebration, from a cosmopolitan and critical thinking perspective. In this experience, we prove that inquiry and critical reflection contribute to the improvement of initial teacher training in a multicultural context.
\end{abstract}

Keywords: action research; pre-school education; training of trainers; intercultural education; language teaching; interdisciplinary approach. 
Historically, Andalusia has been a crossroads of the African and European continents, and also of the Atlantic and Mediterranean seas. As a Spanish monolingual autonomous community, Andalusia bears witness to two festivals running parallel, Halloween and All Saints' Day ${ }^{1}$, both of which have also become standard schools. These two celebrations are highly present in the media as social representations linked to different subcultures and generations. Given the global nature of our world, these representations can be useful as a didactic resource to promote the development of communicative, intercultural, social, and civic skills among students in formal educational institutions. The social representation of Halloween reflects a common historical practice which is based on the recognition of the cycles of life and death, and although its origin was Celtic, it is marked by the contemporary American version of this celebration (Barrera, 2003). Halloween has penetrated education as a means of socialization and of promoting linguistic and cultural knowledge and is used in various activities in schools (Cruz, 2014).

In this context, social representations "permiten interpretar y dar sentido a lo que sucede, a un objeto, a un fenómeno y a los individuos situados en una realidad concreta de nuestra vida" [allow us to interpret and give meaning to what is happening, or to an object, a phenomenon, or individuals within a specific life situation] (Hernández \& Pagès, 2014, pp. 67-68). The collective images of these celebrations can serve as levers for supporting the use of intercultural skills, which are essential for any teacher in the emerging multicultural contexts. According to Lledó (2009), the overload of images we are capable of assimilating should not spoil our thinking potential. Nevertheless, images have been at the core of the visual culture since the beginning of the history of humankind, and this has enabled teachers to use them as triggers to introduce content and concepts in classrooms (Abramowski, 2010). In addition, we know that learning may be improved by internalizing cultural systems of representation and knowledge within a collective framework (Pozo, 2016). Therefore, sharing images through active methodologies is a suitable way of providing future education professionals with tools that give meaning to their teaching practice.

The variety and diversity of people and ways of dealing with existence in a world like ours demands not only a wider but also a deeper development of their intercultural skills (Peñalva \& López Goñi, 2014, p. 142). The 2015 UNESCO Report Replantear la educación. ¿Hacia un bien común mundial? highlighted that while technological developments provide avenues for cooperation and exchange, "we also see the proliferation of cultural and religious intolerance, identity-based political mobilization and conflict" (UNESCO, 2015, p. 10). Despite all of this, the recent literature has pointed out that the education of future with as many skills as possible to deal with the current multicultural environment (Peñalva \& Leiva, 2019; González Monteagudo \& Zamora, 2019). This has been noted in (Santos, Cernadas \& Lorenzo, 2014; Leiva, 2017; Cala, Soriano, \& López Martínez, 2018), books (Escarbajal, 2015), and doctoral dissertations (Gómez Barreto, 2011), all of which have advocated the need to implement IE training programs.

In view of the above, our study sought to address a specific issue: how can pre-service teacher training be improved by using symbolic representations of celebrations in early childhood learning? With this question in mind, we sought to apply pedagogical strategies that would allow pre-service teachers to become familiar with topic-based teaching (Arnau, 1999) of both cultural and language contents (Met, 1999), taking Halloween as the main topic. The starting hypothesis was that both celebrations, Halloween and All Saints' Day, could be used as learning opportunities, as they contribute to enhance the teaching of a globalized and multicultural social reality and give meaning to school knowledge, helping young children understand the symbolic framework that characterizes our world. We used a student-centered learning model (Gargallo et al., 2014) supported by the didactic coordination of two courses from the Early

1 All Saints' Day is a religious celebration in which people pay homage to the dead. Families go to the cemeteries with flowers for their lost ones. The festival is not only a private family tribute to the dead, but it also acts as an intersection between the private, the public, and the ritualistic. Its origin dates back to the 9th century when Pope Gregory IV declared the 1st November as a celebration for the Catholic Church. The name of this feast day refers to both canonized and non-canonized saints. See https://cincodias.elpais. com/cincodias/2016/10/31/sentidos/1477906864_523558.html and https://www.elconfidencial.com/sociedad/2019-10-30/dia-de-todos-los-santos-festivo-celebracion-904_1466152/ 
Education Degree at the University of Almería. The interdisciplinary aim was to promote critical thinking and historical awareness among pre-service teachers to reinforce the education for cosmopolitan citizenship which could strengthen the development of a teaching identity, maintaining a productive tension between the new and the known (Hansen, 2014).

\section{Theoretical Framework}

Our study is informed by Carr and Kemmis' (1988) interpretative and critical theory, as intertwined with the analysis of the socio-discursive interactionism theory (Bronckart, 2010) and with the different dimensions of historical and social thought (Santisteban, González \& Pagès, 2010). Furthermore, it is framed within the basic tenets for text-construction skills (Bronckart, 2010) and critical literacy (Cassany, 2005). We also took into account the Spanish Royal Decree 1393/2007, of 29 October, which establishes the skills to be acquired by university students in their general education and that prepares them for their professional life. Additionally, using Moscovici's (1961) concept of social representation, our study relied on students' prior knowledge in order to help them link the different disciplines and reorganize their knowledge about contemporary society (Castorina, Barreiro \&Carreño, 2012). We aim to support pre-service teachers in further developing and refining their critical awareness of how very young learners interpret school culture. Thus, the focus was on the role of prospective early childhood teachers as agents who have the capacity to take on a social function and accompany infants (as a segment of the social structure) during the development of their identities (Gaitán, 2018). As individuals, we inhabit a time and space, and this fact influences the way we collectively interpret, build and transform stories (Parelleda \& Castorina, 2016, p. 140), specifically the ones built at school. Using social representations of school celebrations, we can make these stories available to children, either to emancipate them or limit them in the construction of their knowledge about their social reality.

The European university curriculum design framework considers both the usefulness and promotion of professional competences regarding not only what to teach, but also to how to teach and the purpose of teaching. This is also the case with the use of social representations in English language teaching. It is our view that when establishing creative teaching and learning processes, any appropriate methodology must take into account that practice entails reflecting on the language and being aware of the different current trends in foreign language teaching (Madrid \& McLaren, 2014; Harmer, 2015). Given the centrality of English in our current world (Kumaravadivelu, 2012), language teaching and didactics should be based on a university curriculum that takes into consideration "instrumental, interpersonal and systemic or integrating competences" (Madrid \& McLaren, 2014, p. 22). As a cross-curricular experience, our aim was also to show our students how Content and Language Integrated Learning (CLIL) would enable them to consider a variety of possibilities (Coyle, 2007), in this case for the early education classroom, which should open avenues for new and collaborative teaching strategies (Méndez \& Pavón, 2012).

It should be added that the different dimensions of both learning and teaching English should be as balanced as possible, with the creative dimension overarching all other skills, in order to achieve not only a better understanding of the intercultural dialogue but also to encourage it (Rainsford, 2018). The European Language Portfolio, as part of the Common European Framework of References for Languages (2001), affirms three key aspects to be fostered in the learning and teaching of languages: learner autonomy, interculturality, and plurilinguism. The Portfolio encourages students to reflect on their level of competencies to be able to transfer the learning outcomes (Gil Sierra \& Nicolás, 2016). This communicative nature of English language teaching is essential for observing the world around us and contributes to dissipating the boundaries of cultural segregation. At the same time, it fosters students' awareness of other realities and challenges their individual perceptions of other people's ways of life and perspectives (Styslinger, Stowe, Walker \& Hostetler, 2019). Hence, the selection of socio-cultural components is inherent in teaching processes, as is the social representation analysis of the cultural environment of foreign languages, which contributes to experiential learning about particular identity-based affiliations. 
These can be recreated either by imposition or subordination, or by helping young children to become emancipated. Therefore, the purpose of reviewing the Halloween season as a social representation of the English-speaking culture in pre-service teacher training can also be understood as a way to promote citizen emancipation.

Reflections on how cultures and subcultures are transmitted or imposed, as well as how they are managed, either through acculturation, or by encouraging interculturality (Gómez Carrasco, Ortuño \& Miralles, 2018, p. 66) may help to further understand and refine the idea that intercultural education (hereinafter IE) is based on the critical analysis of the cultural aspects that cause inequalities (Sleeter 2018a) and exclusion in human relationships. With Aguado and Ballesteros (2015, p. 99), the intercultural approach is "un enfoque teórico desde el que comprender la diversidad humana"2. Furthermore, Soriano and Ballesteros (2015, p. 116) say that interculturality is an opportunity for students to open themselves to self-knowledge processes as well as to know others. We also consider that interculturality is a transdisciplinary task that enables us to face multiculturalism as a process in which identities are shaped through an exchange with other identities (López Sáenz, 2015, p. 78). On this basis, images should be considered as didactic resources that can facilitate both foreign language learning and interculturality as interpretive paradigms of the social reality. Indeed, the teaching of interculturality implies, as Ortega (2007, pp. 44-45) writes, to make changes regarding the language and the contents as well as introducing humanistic attitudes to avoid seeing others beyond the culture they may be sahped.

Today, digital technologies increase citizens' access to the production of images (Aparici, Fernández Baena, García Matilla, \& Osuna, 2012, p. 13) and images use multimodal languages to build and rewrite individual identities, transmit knowledge, and identify group membership. Images have become the flagship of our contemporary lives, with television, the Internet, mobile phones, and social networks being the main examples of audio-visual content production. These environments in which infants grow up cannot be ignored; their social imaginary and their acquisition of skills and knowledge occurs as a result of seeing and observing (Gómez Montoya, Castro, \& Aguadez, 2018, p. 472). Consequently, it is necessary to develop professional competencies that encourage the ability to think critically about the current world. The objective of our teaching experience was, therefore, to bring about a conceptual change and an epistemological breach in what student believe and know about the teaching of the English language and social sciences in the infant stage.

\section{Methodology}

In this paper, we envisage the university classroom as a forum to problematize reality (García Pérez, 2010), and also to examine hegemonic socio-cultural manifestations, promoting a critical and meta-reflective intervention in knowledge. As some authors believe, there can be no education without dialogue and without taking into account today's interrelationships which no longer depend on a particular territory (Martínez Bonafé, 2012). Therefore, the intercultural approach is presented as a tool with which to analyze and interpret our practice in the context of real educational spaces (Aguado, Melero \& Gil Jaurena, 2018, p. 6). Undoubtedly, the promotion of intercultural skills in initial teacher training suggests using collective memory, raising cultural awareness, and thinking about languages and culture as bases for active citizenship, thus giving culture a core meaning as an everyday activity and not as an object (Abdallah-Pretceille, 2006).

Ours is also a qualitative inquiry since we understand the university as a setting where discussing and reviewing professional lines of work should be encouraged. This will enable future teachers to review the role of the contents of school curricula in order to 'co-construct' multiple identities and give a new meaning to citizen's lives. In light of the above, we selected the basic aspects from those proposed by Peñalva and Leiva (2019, p. 39) that could be used to boost IE in the two courses. We reflected on how teachers should act in the present scenario, which is a highly heterogeneous and complex one, where socially-agreed images form a network of emerging representations that educate citizens and can

2 "a theoretical standpoint to better understand human diversity" (our translation). 
determine their learning. This is based on the consideration that "las formas de representación visual, auditiva, cinestética, lingüística, matemática, son modos como los miembros de una cultura 'codifican' y 'decodifican' el significado del entorno" [the forms of representation visual, auditory, kinesthetic, linguistic, mathematical are ways in which members of a culture uniquely 'encode' and 'decode' meaning] (Eisner, 2002, p. 25).

Consequently, Halloween images can be used as resources to transform the teaching practice and construct new meanings for IE through specific didactics in early childhood education degree courses. And thus, we considered using Teixidó et al.'s (2012) contributions on the potential and limitations of popular festival celebrations in schools. Table 1 shows the aspects related to the units of meaning that were analyzed with our sample of university students and were applied to the said images.

\section{Table 1}

Units of Meaning for Analysis (hereinafter UMFA)

\begin{tabular}{|l|l|l|l|l|}
\hline \multicolumn{1}{|c|}{ Unit A } & \multicolumn{1}{c|}{ Unit B } & \multicolumn{1}{c|}{ Unit C } & \multicolumn{1}{c|}{ Unit D } & \multicolumn{1}{c|}{ Unit E } \\
\hline $\begin{array}{l}\text { Tradition versus mo- } \\
\text { dernity }\end{array}$ & Local versus global & $\begin{array}{l}\text { Unit of action versus } \\
\text { professional auton- } \\
\text { omy }\end{array}$ & $\begin{array}{l}\text { Rigidity versus flexi- } \\
\text { ble planning }\end{array}$ & $\begin{array}{l}\text { Educational dimen- } \\
\text { sion versus social } \\
\text { dimension }\end{array}$ \\
\hline
\end{tabular}

Source. Teixidó, J., \& GROC Research Group (2012).

We reflected on what type of roadmap should be developed and which tools should be used. Of all the platforms through which Halloween is made visible, the Internet is the one that makes it possible to access the social imaginary of this seasonal celebration by following the hypertext links (Pozo, 2014) with the help of information and communication technologies. It is then appropriate to include these celebrations in schools, overcoming the false dilemma of whether this festival should be celebrated or not. The socio-cultural and educational sectors respond to this dilemma in different ways, such as those linked to the All Saints' Day religious tradition (Cruz, 2014, p. 8) in contrast with some educational alternatives that are critical of the American influence. This is the case of Hollywins, a Christian set of practices which has recently spread among the different educational contexts in the Western world. Following Pozo (2016), our view is that our teaching model should not turn its back on a set of circumstances which demands a new learning style. This involved carrying out an exercise of collaborative meta-reflection on the opportunity to use this social representation as a focus of interest in the second cycle of early childhood education.

This research experience using a student-centered learning model (Gargallo et al., 2014) was the result of the didactic coordination of two early childhood education degree courses at the University of Almería. These courses were "Foreign language teaching, planning and evaluation (English)" (with 60 students enrolled), and "Social Science Learning in Early Childhood Education" (with 266 students enrolled) and were run during the 2016-2017 and 2017-2018 academic years. Thanks to the ease of access, the unit of analysis was a representative sample of 326 students (93\% women, $7 \%$ men) between 21 and 42 years old. Active teaching methodologies were developed over several stages of the dynamic action research process. After an initial diagnosis, a formal learning model was planned for the said university students, using two types of intervention: one which involved providing expert advice and the other which entailed collaborative advice (Pozo, 2014). Our intention here was to boost the abilities of future teachers as critical agents and researchers of their professional context. For the action research phase, we followed Pérez Gómez's (2012) ideas on the resources which a skilled individual should know how to develop in the face of any problematic situation caused by the coexistence of celebrations such as Halloween and All Saints' Day. To do so, we used a four-stage spiral model in the two didactic areas with the following phases: "(a) análisis y diagnostico comprensivo de las situaciones problemáticas. (b) diseño y planificación de los modos más adecuados de intervención. (c) actuación flexible, sensible, creative y adaptativa. (d) valoración reflexiva de procesos y resultados, así como la formulación de consecuentes propuestas de mejora" [(i) a comprehensive analysis and diagnosis of the problem situation; (ii) design 
and planning of the most appropriate forms of intervention; (iii) a flexible, sensitive, creative and adaptive action; and (iv) a reflective evaluation of the processes and results, as well as formulating the subsequent proposals for improvement] (Pérez Gómez, 2012, p. 146).

In both courses, we asked students how the dimensions of historical and intercultural skills could be used to analyze the celebration of Halloween, and we checked the validity of the units of meaning linked to key concepts in the social sciences as studied by Lee (2005), Seixas and Morton (2013), Van Sledright (2014). We applied key transdisciplinary concepts from the socio-cultural approach of historical education (Barton \& Levstik, 2004; López Facal, Miralles, Prats \& Gómez Carrasco, 2017), such as identity and otherness, change and continuity, conflict, rationality and irrationality, diversity, differentiation and inequality, social organization and interrelation (Benejam, 1999). Also, meta-concepts of time and space were used, taking them from primary and secondary sources of information on the social representations of these celebrations, and the controversies that emerged due to their coexistence and the different ways of narrating them were analyzed as well. Furthermore, we investigated the potential application of a model for the formation of historical thought (Santisteban et al., 2010), based on four dimensions: temporal-historical awareness, representation of history, empathy, and historical interpretation.

A qualitative research methodology was employed to promote understanding and change. We used direct and indirect techniques, interviews (15), discussion groups (10) including personal descriptions of images, and large group discussions to assess the achievements and gather valuable information. We conducted a content analysis of the collected newspapers and portfolios prepared by the students, using the five units of meaning proposed by Teixidó et al. (2012), as well as units of meaning linked to key transdisciplinary concepts of social sciences (Benejam, 1999), and the model of historical thought formation mentioned earlier (Santisteban et al., 2010). An initial and formative evaluation of the teaching and learning process was carried out. Favorable outcomes were obtained for the potential use of these celebrations in school.

Another aspect we took into account was the curriculum development of the early childhood education currently in force in Andalusia (Order August 5th, 2008). We also held a critical, collective reflection-session on the orientation of teaching practices in a hypothetical second-cycle classroom of early childhood education. The said reflection was based on the conceptual and theoretical underpinnings mentioned above, the triangulation of the information collected, and the ensuing process of synthesizing the data obtained. To do this, we analyzed documentary sources such as videos, films, poems, and advertisements in written and audio-visual media shown or published during All Saints' Day and Halloween.

For a better understanding of the action research process, the following figure with the different phases it comprised:

a) Identify needs in teaching training: develop intercultural competencies.

b) Diagnose the situation taking Halloween festival as a didactic resource.

c) Develop an action plan (see Table 2 below).

d) Actions in the classroom.

e) Reflection and evaluation.

Taking the above-mentioned into account, we gave priority to the material developed by the university students in the sample to redefine the official curriculum while being aware that "the transformation of the curriculum involves teaching from different perspectives and points of view" (Sleeter, 2018b, p. 4). The use of the media, newspaper articles, written and audio-visual documents, Internet, songs, videos, poems, and specialized texts on the celebration of Halloween at school were first-rate sources of information. As said above, we felt that we should be open to critical pedagogy and teaching, as school knowledge may go in the direction either of emancipation, or social control. Table 2 below shows the educational action plan which consisted of several phases. Once the plan was developed, we reached 
the reflective phase about the changes experienced in the teaching and learning process carried out in the higher education classroom.

\section{Table 2}

\section{Phases of the Educational Action Plan}

\begin{tabular}{|c|c|}
\hline Phases & Learning situations \\
\hline a) The scenarios of daily life are an ideal field of study. & $\begin{array}{l}\text { The material necessary for the learning comes from: } \\
\text { individual and collective experiences with the audio-vi- } \\
\text { sual display around them, direct sources of information, } \\
\text { economic, social and political conflicts, processes and } \\
\text { structures underlying the cultural conglomerate. }\end{array}$ \\
\hline $\begin{array}{l}\text { b) The everyday cultural space from the perspective of } \\
\text { cooperative and collaborative work in heterogeneous } \\
\text { groups. }\end{array}$ & $\begin{array}{l}\text { A connection between the individual and the universal, } \\
\text { collective dimensions of human identity is fostered. }\end{array}$ \\
\hline $\begin{array}{l}\text { c) The tendency to envisage geographical and historical } \\
\text { spaces as something neutral and distant is counteracted. }\end{array}$ & $\begin{array}{l}\text { Discovering the reason for this situation, revealing hidden } \\
\text { or further motives in various forms of representation. }\end{array}$ \\
\hline $\begin{array}{l}\text { d) Students are advised about the difficulty in and the } \\
\text { potential for analyzing situations from a more critical } \\
\text { viewpoint. }\end{array}$ & $\begin{array}{l}\text { Education is presented as a process that requires time } \\
\text { and dialogue to move away from a stereotyped vision of } \\
\text { education, which is normally focused on a set of easy, fast } \\
\text { and temporary achievements. A complex analysis of the } \\
\text { situations is proposed (Morin, 2001). }\end{array}$ \\
\hline $\begin{array}{l}\text { e) The university students in the sample are offered the } \\
\text { opportunity to discover how complex reality is, and how it } \\
\text { fosters spaces that are not perceived by the naked eye. }\end{array}$ & $\begin{array}{l}\text { Activities are carried out to analyze the hegemonic and } \\
\text { ethnocentric (European and North American) worldview } \\
\text { of numerous cultural processes today. The shared points } \\
\text { that support the plurality of cultural expressions are inves- } \\
\text { tigated. }\end{array}$ \\
\hline $\begin{array}{l}\text { f) The personal experience of the social environment } \\
\text { should not be limited to a mere formal description. }\end{array}$ & $\begin{array}{l}\text { Students question their beliefs and conceptions about the } \\
\text { role of the school as a meeting place for different symbolic } \\
\text { universes. }\end{array}$ \\
\hline $\begin{array}{l}\text { g) Students are shown how some branches of knowledge } \\
\text { have been used to strengthen the hegemonic culture by } \\
\text { marginalizing cultural contents that do not fit in with the } \\
\text { dominant scientific and ideological framework. }\end{array}$ & $\begin{array}{l}\text { Priority is given to subjective narration, not imposed from } \\
\text { the outside, based on the critical analysis of information } \\
\text { sources. The aim is to allow the contributions of everyone } \\
\text { in the group to be heard, gathering their different opinions } \\
\text { and interpretations about the analyzed celebration. Ac- } \\
\text { ademic knowledge and daily knowledge are intertwined. } \\
\text { This ensures a critical approach to school knowledge and } \\
\text { helps detect biases and trends that serve the interests of } \\
\text { which are not visible at first sight. }\end{array}$ \\
\hline
\end{tabular}

Source. Own elaboration.

Results

An evaluation was made of how learning involving the cultural coexistence of Halloween and All Saints' Day could be promoted from a positive perspective. This evaluation focused on the changes that were identified in the type of knowledge, procedures and strategies to be followed, as well as in the changes in attitude and behavior which would strengthen the intercultural skills of early education teachers. The university students in the sample were able to internalize that the discursive structures involved, mainly narratives, were representations of human activity which were generated to provide a greater understanding both of the challenges involved in the activities and of the role of these activities in the development of interpersonal relationships (Ricoeur, 1999).

Regarding the final reflection phase of the action research, students in the sample engaged in a metacognitive exercise to reinforce their learning. This allowed them to observe and assess how children learn about their environment in languages other than their mother tongue from a very early age. A careful observation would obviously entail planning the aims and objectives of both social sciences and English language courses, including the resources, classroom activities, and evaluations. Knowledge of the school context, awareness of cultural diversity, and reflection on teaching practice in today's multicul- 
tural environment are required. In the education field, we speak about a learning experience when we are not indifferent to it, that is, when its impact is significant enough to engage us and leave an impression on us (Contreras \& Pérez de Lara, 2013, p. 24). In our view, if generalist teachers became aware of the dimensions of cultural movements and looked at them through the screens of the various devices and a specific educational approach, analyzing their causes, changes and consequences (used as second order concepts), they would be more likely to act and redirect the attention of their students towards the most appropriate social representations, using a critical and transformative intercultural approach. We advocate setting up a transitional movement from a dominant, conventional and academic type of knowledge to a more transformative one, which can help students to develop and polish the knowledge of their multiple identities and of how globalization affects their lives (Banks, 2015, p.23). This was the approach we used to study Halloween in the university classroom. Further below, we provide some evidence, in the form of excerpts from our students' reports, about our work on intercultural, democratic, cosmopolitan, and active education as one of the main purposes of teaching in school.

It should be added that globalization largely promotes a discourse of performance (Debord, 2000), among other factors, which may influence the construction of the professional identities. It is for this reason we thought we should consider how to combine this knowledge and transfer it to children's classrooms. Difficulties are understandable when teachers fall into the identity quicksand, mediated by different agents, as they participate in building children's individual and collective identities. As identities may be constructed from "deterritorialized" life events (Cabrera \& Bartolomé, 2007, p. 191), we invited our students to think about early education teachers' use of images related to the celebration of Halloween at the end of October to socialize their students, and to wonder about other meaningful celebrations, such as Eid al Adha (the "Festival of Sacrifice") or the Chinese New Year, which are not used in class as frequently as the aforementioned ones are.

Once this process had been completed, we began the action research final reflection phase by selecting some of the students' reports which answered the following questions: Do we have to work on celebrating Halloween in the second cycle of early childhood education? Why and with what purpose? Three different positions were recorded: a) $85 \%$ of students were in favor of using the social representation of Halloween in the classroom; b) $10 \%$ referred to both the reasons to use it and not to use it, and c) $5 \%$ rejected using this representation in the classroom. Some representative arguments of the majority's position are presented below, and can be linked to key transdisciplinary concepts (Benejam, 1999) and the units of meaning outlined by Teixidó et al. (2012) in Table 1 above: tradition vs. modernity, local vs. global, unit of action vs. professional autonomy, rigidity vs. flexible planning, and the educational dimension vs. social dimension:

Es importante trabajar la festividad de Halloween. Vivimos en una sociedad en la que a los niños se les ocultan realidades en el aula, (...) sin darnos cuenta de que viven en una sociedad rodeada de tecnologías (tv, radio, ordenador) y personas que comentan estas informaciones. (...) Considero que debo trabajar celebraciones de este tipo, aunque no tengan su origen en la tradición histórica de este país, fomentará un mejor conocimiento de los países de habla inglesa y de sus tradiciones." (Alumna 12, $3^{\circ} \mathrm{A}$ ). [UMFA: A. Conceptos clave transdisciplinares: diversidad; cambio y continuidad; interrelación]. ${ }^{3}$

Como futura docente, me parece una gran oportunidad, de este modo los alumnos pueden conocer distintas culturas y acercarse a la lengua extranjera. En educación infantil se otorga importancia a este tipo de fiestas, ya que el alumnado disfruta mucho. Se lo pasan genial disfrazándose

3 It's important to do some work on the Halloween festival. We live in a society where real situations are hidden from children in the classroom, (...) without realizing that they live surrounded by technology (TV, radio, computers) and people who discuss this information. (...). I believe that I should do some work with my students on celebrations of this kind, and even if their historical tradition is not Spanish, it will foster a better knowledge of the English-speaking countries culture and traditions. (Student 12, 3rd A) [UMFA: A. Key transdisciplinary concepts: diversity; change and continuity; interrelation]. (Our translation). 
y pasando un poco de miedo." (Alumna $21,4^{\circ} \mathrm{C}$ ). [UMFAs: C y D. Conceptos clave transdisciplinares: diversidad; interrelación; racionalidad e irracionalidad]. ${ }^{4}$

Additionally, as evidence of the final reflection process, we include some fragments of the arguments provided by three discussion groups at the end of the teaching experience. Next, some arguments by three discussion groups are offered. These were produced at the end of the reflection and evaluation phase of the action research process. As can be seen, the students value this festivity and its celebration since, for them, it may contribute to both bringing key transdisciplinary concepts to the classroom, as those of change and continuity, and to think historically by introducing the principle of temporality with children by connecting past-present-future. Moreover, our students are aware of the globalized world we live in, in which English, as a lingua franca, is culturally charged as hegemonic through the mass media and the Internet:

El estudio y conocimiento de la festividad de Halloween nos pueden ayudar en la educación infantil para desarrollar el pensamiento histórico, no sólo para que tomen conciencia del origen de esta celebración, sino también para que observen cómo la historia pasada sigue presente en la actualidad. [GDD3EIA. UMFA: A. Conceptos clave transdisciplinares: racionalidad; cambio y continuidad; diversidad]. ${ }^{5}$

Considero crucial trabajar la interculturalidad y tratar en el aula las diferentes tradiciones y costumbres de la sociedad globalizada en la que nos situamos, en concreto en el aprendizaje del inglés. La festividad de Halloween, en los últimos años, se ha implantado fuertemente en nuestro país. Esta temática nos ayuda a incorporar el significado de patrimonio cultural y lingüístico. Es fundamental que los alumnos/as, desde edades tempranas conozcan las circunstancias para que la fiesta haya llegado hasta nuestra sociedad." [GDD4EIB. UMFAs: B y E. Conceptos clave transdisciplinares: diversidad y diferenciación; interrelación; diversidad]. ${ }^{6}$

Es conveniente que los niños sepan su origen. Acercaremos a los niños desde el origen hasta la actualidad. Trabajaremos los conceptos clave de cambio y continuidad y el principio de temporalidad para conectar la época de los celtas y ver cómo ha ido evolucionando, careciendo de sentido religioso hasta formar parte de nuestra sociedad y cultura consumista. [GDD3EIC. UMFAs: A, C y E. Conceptos clave transdisciplinares: racionalidad; cambio y continuidad; diversidad; organi-

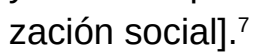

We are aware that the stories and narratives presented above cannot be generalized to other contexts since they correspond to a formative experience developed in a specific space and time, but their relevance lies in the fact that they are the consequence of a training process carried out in the university classroom to bring about changes in teaching practice.

\section{Discussion}

Our aim in this paper was to share what we do in the university classroom and why we do it, in view of the fact that we always seek to improve our professional performance and specialization as

4 As a future teacher, I think it is a great opportunity; students can learn about different cultures, and it helps in how they approach foreign languages. In early childhood education, importance is given to these types of festivities because students enjoy them a lot. They have a great time dressing up and enjoy being scared. (Student 21, 4th C) [UMFAs: C and D. Key transdisciplinary concepts: diversity; interrelation; rationality and irrationality]. (Our translation).

5 The study and knowledge of the Halloween festival can help us in early childhood education to develop children's historical thinking, not only to make them aware of the origin of this celebration but also to observe how the past is still present today. [GDD3EIA. UMFA: A. Key transdisciplinary concepts: rationality; change and continuity; diversity]. (Our translation).

6 I believe it is crucial to work interculturally and deal with the different traditions and customs of our globalized society, particularly when learning English. Halloween has become quite popular in Spain in recent years, which helps us incorporate the meaning of cultural and linguistic heritage. From an early age, it is essential for students to know the circumstances in which this festival has reached our society. [GDD4EIB. UMFAs: B and E. Key transdisciplinary concepts: diversity and differentiation; interrelation; diversity]. (Our translation).

7 It is important for children to know about their origin. We will use an approach that will take them from the origin to the present time. We will work on the key concepts of change and continuity and the principle of temporality to connect them with the period of the Celts, looking at how it evolved, with no religious meaning, until it became part of our consumerist society and culture. [GDD3EIC. UMFAs: A, C and E. Key transdisciplinary concepts: rationality; change and continuity; diversity; social organization]. (Our translation). 
reflective trainers (Perrenoud, 2004). Undoubtedly, when we examine other trainers from a pedagogical point of view, we run the risk of diverting attention from our analysis of what we do as trainers of trainers (Zabalza, 2014). Thus, our interest in self-investigating our teaching practices is twofold: firstly, to investigate how we carry out our work, since we are concerned about its quality, and secondly, to improve the training processes of future teachers. We aim to train professionals who are critical, reflective, and investigative of their own teaching practice (Pérez Gómez, 2019). To this end, we offered our students a vision of social sciences and culture in the English language that overcomes the static representation of the curriculum which separates the different disciplines, by raising awareness of the curriculum fragmentation of knowledge.

This formative experience, based on action research, is innovative in that it offers the development of two apparently independent learning modules in initial early childhood education training through a common theoretical-practical framework, the IE paradigm, in order to improve teaching actions yet to come in multicultural socio-educational contexts in Andalusian schools. Both subjects (Foreign Language (English) Teaching, Planning and Evaluation, and Social Science Learning in Early Childhood Education) achieve this by using the Halloween festival as an opportunity for learning, and generating a direct relationship between educational research and its implementation in the children's classroom. Thus, the classic dichotomy in the field of educational research between theory and practice is resolved.

We know from experience that one of the aims of most educational plans and projects in Andalusian schools is to encourage the coexistence of cultures. The structure of these two courses in the degree was planned on the basis of four objectives to foster an intercultural approach: (1) to embrace diversity as a factor for educational quality and social equity; (2) to promote equal academic opportunities for the various cultural processes; (3) to improve the self-esteem of university students and their personal and cultural self-concept as future teachers; and (4) to increase their critical and reflective capacity in connection with the spatial and temporal setting in which they live.

As stated earlier, we put into practice new ways of dealing with complex knowledge (Morin, 2001) in that we drew on social representations to rethink our identity and teaching practice in multicultural environments. To do this, we jointly discussed the importance of decision making based on reflective action and on principles that promote the universal, democratic, and IE of citizens in the classroom. However, it was not always easy to stimulate this action-research qualitative approach, as it required that the future teachers were motivated and driven by ethics. A constant reflective effort was made to engage students in shared self-evaluation, which they are not used to doing, in order to establish real practices in the different school environments. Students were invited to identify implicit theories (Pozo, 2016) which they may have internalized during their pedagogical experiences of foreign language and social science teaching in their pre-university years and which sometimes prevented or hindered them from working towards changes.

\section{Conclusions}

This study confirmed that social representations are a cultural product marked by ideologies, the media, the socio-economic and political context, and intellectual fads and beliefs that operate in the community. Our students were able to see how reality is characterized by transience, the dizzying pace of events, and the influence of the audio-visual culture, market values, and neoliberal policies. The approach to the Halloween festival enabled us to review how the identities traditionally rooted in the hegemonic model of the nation-state have been reconstructed through concepts such as time, space, territory, border, language, and culture. Interestingly, these identities, characterized by their uniformity, have two different trends in that they are becoming weaker and more vulnerable while at the same time they are being strengthened by means of representations and images. That is, it was confirmed that Halloween and All Saints' Day are thought about via simplified difference and opposition discourses: whereas Halloween is constructed as a commercially-based festival linked mainly to the social group of children, All Saints' Day is perceived as an opportunity for showing emotion in remembering the dead through a religious ritual which is recognized by a broad sector of the adult community. 
Part of this project aimed to review, reorient, and restructure the implicit theories students have about the teaching role to be able to trigger transformations in their professional practice, as shown in the selected views about the celebration of Halloween. School curricula must be planned from a critical intercultural perspective that overcomes certain deviations, such as those that minimize the cultural dimension as a pedagogical factor, maintain a romantic and folklorist conception of cultural diversity, or show a tendency towards social compassion, i.e., as a principle that looks at cultural diversity from the socio-economic vulnerability of certain social groups (Leiva, 2017, pp. 30-31).

With this paper we hope to have been able to provide sufficient knowledge about the use of a celebration as a didactic object to guide decision making that seeks to improve IE. We believe that further reflective efforts should be made by the schools concerning the real application of the training experiment, either through a follow-up in external practices or in the first years of professional activity. Thus, although the said training experiment does not guarantee the use of the intercultural approach in any educational context, it can be viewed as a shared experience of the innovative potential of this approach that could be adopted in order to recognize cultural diversity as a pedagogical and didactic resource. Future research may be able to inform us about whether the lessons learned in this intercultural approach have been applied in the early childhood education classrooms.

\section{References}

Abdallah-Pretceille, M. (2006). El paradigma intercultural como mirada hacia la diversidad. In Proceedings of INTER-International Congress on Intercultural Education "Formación del profesorado y práctica escolar" organized by the UNED, Madrid, 15th-171th March 2006. Madrid: Servicio de Publicaciones UNED. http://www.uned.es/congreso-inter-educacion-intercultural

Abramowoski, A. (2010). ¿Es posible enseñary aprender a mirar? El Monitor de la Educación, 13 [Ministry of Education, Argentina]. http://repositorio.educacion.gov.ar:8080/dspace/handle/123456789/94769

Aguado, T. and Ballesteros, B. (2015). Investigando la escuela intercultural. Experiencias y resultados del Grupo INTER. In A. Escarbajal (Ed.), Comunidades interculturales y democráticas: Un trabajo colaborativo para una sociedad inclusiva (pp. 99-112). Narcea.

Aguado, T., Melero, H. S.,\&l. Gil Jaurena. (2018). Espacios y prácticas de participación ciudadana. Propuestas educativas desde una mirada intercultural. RELIEVE, 24(2). doi:http://doi.org/10.7203/ relieve.24.2.13194

Aparici, R., Fernández Baena, J., García Matilla, A., \& Osuna, S. (2012). La imagen. Análisis y representación de la realidad. Gedisa.

Arnau, J. (1999). Second language teaching through contents: An introduction. Journal for the Study of Education and Development/ Infancia y Aprendizaje, 22(86), 5-11. doi:https://doi. org/10.1174/02103709960293801

Banks, J. A. (2015). Emigración global, diversidad y educación para la ciudadanía. In A. Escarbajal (Ed.), Comunidades interculturales y democráticas: Un trabajo colaborativo para una sociedad inclusiva (pp. 15-24). Narcea.

Barrera, M. (2003). Halloween: su proyección en la sociedad estadounidense [Doctoral Dissertation]. Complutense University, Madrid. https://eprints.ucm.es/4758/1/T26709.pdf

Barton, K. C., \& Levstik, L. S. (2004). Teaching History for the Common Good. Lawrence Erlbaum Associates.

Benejam, Pilar. (1999).La oportunidad de identificar conceptos clave que guíen la propuesta curricular. Iber, 21, 5-12.

Bronckart, J. P. (2010). La enseñanza de lenguas: para una construcción de las capacidades textuales. In J. P. Bronckart (Ed.), Desarrollo del lenguaje y didáctica de las lenguas (cap. 7). Miño y Dávila.

Cabrera, F., \& Bartolomé, M. (2007). Construcción de una ciudadanía intercultural y responsable. Narcea. 
Cala, V. C., Soriano, E., \&López Martínez, M. J. (2018). Actitudes hacia personas refugiadas y ciudadanía europea inclusiva. Análisis para una propuesta educativa intercultural con el profesorado en formación. RELIEVE, 24(2). doi:https://doi.org/10.7203/relieve.24.2.13320.

Carr, W.,\&Kemins, S. (1988). Teoría crítica de la enseñanza. La investigación-acción en la formación del profesorado. Martínez-Roca.

Cassany, D. (2005). Investigaciones y propuestas sobre literacidad actual: multiliteracidad, internet y criticidad. Concepción, Chile: Cátedra UNESCO para la Lectura y la Escritura-University of Concepción. http://www2.udec.cl/catedraunesco/05CASSANY.pdf

Castorina, J. A., Barreiro, A., \& Carreño, L. (2012). El concepto de polifasia cognitiva en el estudio del cambio conceptual. In M. Carretero, \& J. A. Castorina (Eds.), La construcción del conocimiento histórico. Enseñanza, narración e identidades. Paidós.

Common European Framework of Reference for Languages. 2001. Council of Europe. https://www.coe.int/en/web/common-european-framework-reference-languages

Contreras, J., \& Pérez de Lara, N. (Eds.). (2013). Investigar la experiencia educativa. (2nd edition). Morata.

Coyle, D. (2007). Content and Language Integrated Learning: Towards a connected research agenda for CLIL pedagogies. International Journal of Bilingual Education and Bilingualism, 10(5), 543-562 doi:10.2167/beb459.0.

Cruz, C. (2014). Lo que llevamos a las aules: el paradigma Halloween. Grado en Educación Primaria. Úbeda (Spain): Centro de Profesorado SAFA, University of Jaén. Retrieved March 13, 2020. from https://magisterio.safa.edu/images/C_Cruz_Ortiz.pdf.

Debord, G. (2000). La sociedad del espectáculo. Pre-Textos.

Eisner, E. W. (2002). La escuela que necesitamos. Ensayos personales. Amorrortu Ed.

Escarbajal, A. (2015). Comunidades interculturales y democráticas: un trabajo colaborativo para una sociedad inclusiva. Narcea.

Gaitán, L. (2018). Los derechos humanos de los niños: ciudadanía más allá de las '3Ps'. Sociedad e Infancias, 2, 17-37.

García Pérez, F. (2010). La investigación en didáctica de las ciencias sociales y la construcción del conocimiento profesional de los docentes. En R. M. Ávila, P. Rivero, \& P. L. Domínguez (Eds.), Metodología de investigación en Didáctica de las Ciencias Sociales (pp. 399-416). Institución Fernando EI Católico (CSIC)-AUPDCS.

Gargallo, B., Morera, I., Iborra, S., Climent, M. J., Navalón, S., \& García Félix, E. (2014). Metodología centrada en el aprendizaje. Su impacto en las estrategias de aprendizaje y en el rendimiento académico de los estudiantes universitarios. Revista Española de Pedagogía, 259 (Year LXXII), 415-435.

Gil, A. F., \& Nicolás, S. (2016). Nuevas tendencias en la didáctica de las lenguas extranjeras aplicadas al entorno profesional: la grabación audiovisual con enfoque interdisciplinar. Porta Linguarum, 26 (June), 121-134. from http://hdl.handle.net/10481/53939

Gómez Barreto, I. M. (2011). La competencia intercultural en la formación inicial de los maestros de educación infantil en la Universidad de Castilla-La Mancha [Doctoral Dissertation]. Universidad Nacional de Educación a Distancia, Madrid. Retrieved March 13, 2020 from https://dialnet.unirioja.es/servlet/tesis?codigo $=43429$

Gómez Carrasco, C. J., Ortuño, J., \& Miralles, P. (2018). Enseñar ciencias sociales con métodos activos de aprendizaje. Reflexiones y propuestas a través de la investigación. Octaedro.

Gómez Montoya, P. A., Castro, A., \& Aguadez, J. I. (2018). La publicidad con ojos de niño: imaginarios infantiles y construcción crítica de significados. Aula Abierta, 47(4), 471-480. 
González-Monteagudo, J. „\& Zamora, M. (2019). Los profesores y los desafíos de las diversidades y de las migraciones en España: formación y políticas educativas. Revista de Educação Pública, 28(68), 275-296.

Hansen, D. T. (2014). El profesor cosmopolita en un mundo global. Buscando el equilibrio entre la apertura a lo nuevo y la lealtad a lo conocido. Narcea.

Harmer, J. (2015). Essential Teacher Knowledge. Core Concepts in English Language Teaching. Pearson.

Hernández Cervantes, L., \& Pagès, J. (2014). La enseñanza de las Ciencias Sociales en la educación infantil en México: las representaciones sociales y la práctica docente de nueve estudiantes de maestra de educación infantil. Educação em Revista, 30(1), 65-94.

http://www.scielo.br/pdf/edur/v30n1/a04v30n1.pdf

Kumaravadivelu, B. (2012). Language teacher education for a global society: A modular model for knowing, analyzing, recognizing, doing, and seeing. Routledge.

Lee, P. (2005). Putting principles intro practice: Understanding history. In M. Donovan, \& J. Bransford (Eds.), How students learn: History in the classroom (pp. 31-77). National Academies Press.

Leiva, J. J. (2017). La Escuela Intercultural hoy: reflexiones y perspectivas pedagógicas. Revista Complutense de Educación, 28(1), 29-43.

Lledó, E. (2009). Ser quien eres. Ensayos para una educación democrática. Prensas Universitarias de Zaragoza.

López Facal, R., Miralles, P., Prats, J. (Dirs.), \& Gómez Carrasco, C.J. (Coord.). (2017). Enseñanza de la historia y competencias educativas. Graó.

López Sáenz, M. C. (2015). Diálogo intercultural. ¿Una utopía del siglo XXI? Pensamiento. Revista de Investigación e Información Filosófica, 71(265), 73-94. doi:10.14422/pen.v71.i265.y2015.004

Madrid, D., \& McLaren, N. (Eds.). (2014). TEFL in Primary Education. Universidad de Granada.

Martínez Bonafé, J. (2012). La educación (social) y sus pedagogías. Cuadernos de Pedagogía, 422 (April), 88-91.

Méndez, M. C., \& Pavón, V. (2012). Investigating the coexistence of the mother tongue and the foreign language through teacher collaboration in CLIL contexts: Perceptions and practice of the teachers involved in the plurilingual programme in Andalusia. International Journal of Bilingual Education and Bilingualism, 15(5), 573-592. doi:10.1080/13670050.2012.670195

Met, M. (1999). Impulsando el desarrollo de la segunda lengua mediante la enseñanza de contenidos. Promoting second language development through content teaching. Journal for the Study of Education and Development/Infancia y Aprendizaje, 22(86), 13-26. doi:10.1174/02103709960293810

Morin, E. (2001). Los siete saberes necesarios para la educación del futuro. Paidós.

Moscovici, S. (1961). La psychanalyse, son image et son public. Presses Universitaires de France.

Order of August 5th, 2008 [Andalusian Official Bulletin, BOJA No. 169], which established the curriculum of Early Childhood Education in Andalusia.

Order of December 27th, 2007 [No. ECl/3854/2007], which established the requirements for the verification of official university degrees for entry into the teaching profession in Early Childhood Education.

Ortega, P. (2007). Educación intercultural y migración. Propuestas educativas para la convivencia. In E. Soriano (Coord.). Educación para la convivencia intercultural, (pp. 25-58). La Muralla.

Parellada, C. A.,\& Castorina J. A. (2016). Conocimientos históricos de los alumnos: cultura y política. Enseñanza de las Ciencias Sociales, 5, 133-144. doi:10.1344/ECCSS2016.15.12

Peñalva, A.,\& Leiva, J. J. (2019). Metodologías cooperativas y colaborativas en la formación del profesorado para la interculturalidad. Tendencias Pedagógicas, 33, 37-46. doi:10.15366/tp2019.33.003. 
Peñalva, A.,\& López-Goñi, J.J. (2014). Competencias ciudadanas en alumnado de magisterio: la competencia intercultural personal. Revista Electrónica Interuniversitaria de Formación del Profesorado, 17(2), 139-153. doi:10.6018/reifop.17.2.196871

Pérez Gómez, Á. I. (2012). Educarse en la era digital. Morata.

Pérez Gómez, A.I. (2019): Ser docente en tiempos de incertidumbre y perplejidad. Márgenes. Revista de Educación de la Universidad de Málaga, O(0), 3-17. doi:10.24310/mgnmar.v0i0.6497

Perrenoud, P. (2004). Desarrollar la práctica reflexiva en el oficio de enseñar. Profesionalización y razón pedagógica. Graó.

Pozo, J. I. (2014). Psicología del aprendizaje humano. Adquisición de conocimiento y cambio personal. Morata.

Pozo, J. I. (2016). Aprender en tiempos revueltos. La nueva ciencia del aprendizaje. Alianza Editorial.

Rainsford, D. (2018). Futures for English studies: teaching language, literature and creative writing in higher education [Book Review]. English Studies, 99(2), 224-226. doi:10.1080/00138 38X.2018.1420740

Ricoeur, P. (1999). La lectura del tiempo pasado: memoria y olvido. Ediciones de la Universidad Autónoma de Madrid.

Royal Decree of October 29th, 2007 [No. 1393/2007], which establishes the competences to be acquired by the university student in their general training, which is aimed at the preparation of professionals.

Santisteban, A., González, N., \& Pagés, J. (2010). Una investigación sobre la formación del pensamiento histórico. In R. M. Ávila, P. Rivero, \& P. L. Domínguez (Eds.), Metodología de investigación en didáctica de las ciencias sociales (pp. 115-128). Institución Fernando El Católico (CSIC)-AUPDCS.

Santos, M. A., Cernadas, F. X., \& Lorenzo, M. M. (2014). La inclusión educativa de la inmigración y la formación intercultural del profesorado. Revista Electrónica Interuniversitaria de Formación del Profesorado, 17(2), 123-137. doi:10.6018/reifop.17.2.196931.

Seixas, P., \& Morton, T. (2013). The big six historical thinking concepts. Toronto: Nelson.

Sleeter, C. E. (2018a). Multicultural education past, present, and future: struggles for dialog and power-sharing. International Journal of Multicultural Education. 20(1): 5-20. doi:10.18251/ijme.v20i1.1663

Sleeter, C. E. (2018b). La transformación del currículo en una sociedad diversa: ¿quién y cómo se decide el currículum? RELIEVE, 24(2). doi:10.7203/relieve.24.2.13374

Soriano, E. and Peñalva, A. (2015). La formación inicial del profesorado en interculturalidad. In A. Escarbajal (Ed.), Comunidades interculturales y democráticas: Un trabajo colaborativo para una sociedad inclusiva (pp. 113-126). Narcea.

Styslinger, M. E., Stowe, J., Walker, N.,\&Hyatt Hostetler, K. (2019). Becoming Teachers for Social Justice: Raising Critical Consciousness. The Clearing House. A Journal of Educational Strategies, Issues and Ideas, 92(1-2), 9-14. doi:10.1080/00098655.2018.1533797

Teixidó, J.,\& GROC Research Group (2012). Celebración de fiestas populares en la escuela [Final report of the ethnographic-collaborative study linked to Project 'Xogábase e xógase, se contaba y se cuenta, es dansava y es dansa, s'escolatava y se escolta' (2010 Call), carried out by the Bitàcola-GROC research group]. University of Girona.

http://www.joanteixido.org/doc/festestradicionals/celebracion_fiestas_escuela.pdf

UNESCO. (2015). Replantear la educación. ¿Hacia un bien común mundial? Paris: United Nations Educational, Scientific and Cultural Organization. https://unesdoc.unesco.org/ark:/48223/pf0000232697 
Van Sledright, B. A. (2014). Assessing Historical Thinking and Understanding. Innovative Designs for New Standards. Routledge.

Zabalza, M. A. (2014). Prólogo. In Á. Domingo, \& M. V. Gómez Serés (Eds.), La práctica reflexiva: bases, modelos e instrumentos (pp. 7-14). Narcea. 